\title{
Analisis Pengelolaan Perusahaan Daerah Pasar Kota Manado Dalam Mewujudkan Good Corporate Governance
}

\author{
FRISKA LANGELO ${ }^{1}$, GRACE.B.NANGOI ${ }^{2}$, JESSY.D.L.WARONGAN ${ }^{3}$ \\ ${ }^{1,2,3}$ Program Magister Akuntansi, Fakultas Ekonomi dan Bisnis Universitas Sam Ratulangi \\ email: friskalangelo@yahoo.co.id ${ }^{1}$, gracebn@yahoo.com², jdimarcus@gmail.com ${ }^{3}$
}

\begin{abstract}
This study aims to analyze the management of Market Regional Company or PD Pasar Manado in establishing Good Corporate Governance (GCG). This research is a qualitative exploratory approach. Data were obtained by indepth interviews, observation and documentation study. The result shows that the management of PD Pasar Manado in realizing GCG has been in accordance to the General Guidelines of GCG, issued by the National Commission on Governance Policy. GCG includes the principles of transparency, accountability, responsibility, independence, and fairness. However, there are some obstacles in managing PD Pasar Manado to implement GCG. The biggest problem is in the principle of accountability. The next ones are the principle of responsibility, the principle of fairness, the principle of transparency, and the principle of independence. These constraints are in bureaucratic structures, resources, executor attitude and communication, and environmental constraints of economic, social and political. Basically, all the constraints in the management of PD Pasar Manado in realizing good corporate governance are related to each other. The greatest obstacle in facing each principle of GCG is in its resource and environmental constraints of economic, social and political. They influence significantly management of PD Pasar Manado, i.e the lack of contribution to regional revenue Manado. In light of this, the management of PD Pasar Manado needs to be improved, specifically in its implementation of $G C G$.
\end{abstract}

Keywords: Good Corporate Governance, Regional Company of Market

\begin{abstract}
Abstrak. Penelitian ini bertujuan menganalisis pengelolaan Perusahaan Daerah (PD) Pasar Kota Manado dalam mewujudkan Good Corporate Governance (GCG). Penelitian ini adalah penelitian kualitatif dengan pendekatan eksploratori. Data diperoleh melalui teknik wawancara mendalam, observasi dan studi dokumentasi. Hasil penelitian menunjukkan bahwa pengelolaan PD Pasar Kota Manado dalam mwujudkan GCG telah sesuai dan dilaksanakan berdasarkan Pedoman Umum GCG Indonesia yang dikeluarkan oleh Komisi Nasional Kebijakan Governance (KNKG) yang meliputi asas transparansi, akuntabilitas, responsibilitas, independensi, serta kewajaran dan kesetaraan. Namun, dalam pengelolaan PD Pasar Kota Manado dalam mewujudkan GCG masih ditemukan beberapa kendala dalam setiap asas GCG. Asas akuntabilitas merupakan asas yang paling banyak memiliki kendala, yang kedua asas responsibilitas, kemudian asas kewajaran dan kesetaraan selanjutnya yang keempat asas transparansi, dan yang terakhir adalah asas independensi. Kendala-kendala tersebut yaitu kendala struktur birokrasi, sumber daya, sikap pelaksana dan komunikasi serta kendala lingkungan ekonomi, sosial dan politik. Pada dasarnya, semua kendala dalam pengelolaan PD Pasar dalam mewujudkan GCG saling berhubungan satu dengan yang lainnya. Dimana kendala yang paling besar dihadapi untuk setiap asas GCG adalah kendala sumber daya dan lingkungan ekonomi, sosial dan politik yang sangat mempengaruhi pengelolaan PD Pasar, seperti kurangnya kontribusi terhadap Pendapatan Asli Daerah (PAD) Kota Manado. Karena PD Pasar merupakan salah satu sumber PAD Kota Manado, maka perlu adanya pengaturan lebih baik terhadap Pasar yang ada di Kota Manado, terutama adanya penerapan GCG pada PD Pasar.
\end{abstract}

Kata kunci: Tata Kelola Perusahaan yang Baik, Perusahaan Daerah Pasar

\section{Pendahuluan}

Pelaksanaan otonomi daerah di Indonesia menjadi titik fokus yang penting dalam memperbaiki kesejahteraan daerah. Secara khusus otonomi daerah menginginkan daerah memiliki kemampuan dalam menggali dan mengembangkan sumber daya yang dimiliki sehingga derajat kapasitas fiskalnya mampu memenuhi tuntutan pembiayaan pembangunan di daerahnya. Salah satu komponen terpenting sumber pembiayaan pembangunan daerah adalah PAD. Komponen inilah harus dikelola secara lebih efisien dan efektif agar semakin kuat perananya dalam memperkecil ketergantungan pemda pada pemerintah pusat di bidang pembiayaan pembangunan (Santo, 2016). Dalam upaya penguatan penerimaan daerah yang bersumber dari PAD, maka peranan investasi pemerintah melalui Badan Usaha Milik Daerah (BUMD) sangat diharapkan. Selain sebagai sumber PAD, BUMD diharapkan juga sebagai pemacu utama pertumbuhan dan pembangunan ekonomi daerah (engine of growth), sehingga mampu menimbulkan efek multiplier yang besar (Santo, 2016). 
Sebagaimana sebuah perusahaan, perusahaan daerah dapat mengalami kerugian. Kerugian tersebut dapat disebabkan oleh buruknya pengelolaan perusahaan daerah karena dilakukan tanpa memperhatikan prinsip-prinsip GCG. Selain itu kerugian juga dapat disebabkan karena tidak berfungsinya sistem perencanaan dan pengendalian internal (Turiman, 2011). Begitu juga dengan Pemerintah Kota (Pemkot) Manado juga memiliki BUMD yang diharapkan dapat berkontribusi dalam PAD. Salah satu BUMD Pemkot Manado, yaitu Perusahaan Daerah (PD) Pasar Kota Manado.

Berdasarkan studi pendahuluan (preliminary survey) yang peneliti lakukan, banyak terdapat masalah dalam pengelolaan PD Pasar Kota Manado. Ada pula beberapa tulisan yang berhasil dihimpun, baik dari berita online yang telah dikonfirmasi dengan pihak terkait, sebagai berikut: 1) adanya salah satu fraud yang berhasil diungkap. Kasus korupsi yang dilakukan oleh mantan Direktur Utama (Dirut) PD Pasar Kota Manado periode 2012-2013. Hal ini merupakan temuan dari Badan Pemeriksa Keuangan (BPK); 2) hingga memasuki semester kedua di tahun 2015, target PD pasar masih nihil. PD Pasar sudah sekitar dua tahun tersebut (TA 2013-2015), tidak memberi kontribusi ke kas Pemkot Manado. Dalam perkiraan Komisi B bahwa setiap bulan PD Pasar bisa meraup pendapatan Rp.300 juta, sehingga dalam setahunnya capaian mereka bisa Rp.3,5 miliar dan biaya operasionalnya bisa Rp.1,05 miliar. Saldo yang tersimpan di kas PD Pasar sekitar Rp.2,6 miliar dalam setahun, herannya tidak ada yang disetorkan ke kas daerah. Selain itu juga belum adanya peraturan daerah (perda) yang jelas mengatur tentang bagi hasil dan perda tentang penyertaan modal bagi PD Pasar dengan Pemkot Manado. Berikut rekapan besaran penyetoran PAD dari PD Pasar Kota Manado, sebagai berikut.

\section{Gambar 1. Rekap PAD PD Pasar Kota Manado}

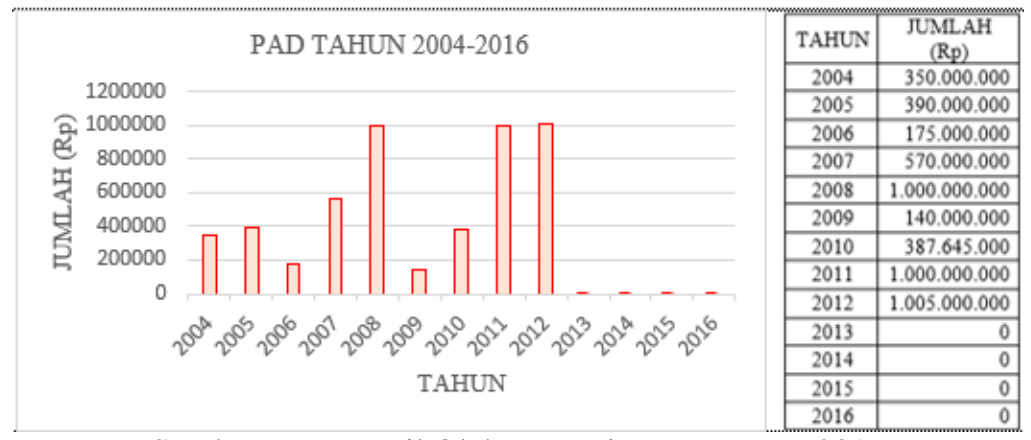

Sumber: Data Hasil Olahan, Bagian Keuangan, 2017

Berdasarkan Gambar 1. dapat dikaji bahwa besaran kontribusi PD Pasar Kota Manado untuk PAD Kota Manado mengalami kenaikan dan penurunan tiap tahun. Tahun 2009 adalah besaran PAD terendah yaitu hanya sebesar 3\% dan tahun 2012 merupakan besaran PAD tertinggi yaitu sebesar 20\% dari total PAD dari tahun 2004 sampai tahun 2012 sebesar Rp.5.017.645.000,-. PD Pasar hanya menyetor PAD sampai dengan tahun 2012, tidak ada penyetoran PAD lagi oleh PD Pasar untuk tahun 2013 sampai dengan tahun 2016. Jika dikaitkan dengan Pendapatan Hasil Pengelolaan Daerah yang Dipisahkan tahun 2011 dan tahun 2012 PD Pasar berkontribusi terhadap PAD Pemkot Manado sebesar 53\% dan 50\% dari total pendapatan Pemkot Manado tahun 2011 dan tahun 2012. Sebagai BUMD PD Pasar seharusnya menjadi salah satu yang memberikan sumber pendapatan bagi pemerintah daerah untuk meningkatkan PAD. PD Pasar wajib untuk menjalankan tugas dan fungsinya secara profesional sesuai dengan asas-asas tata kelola perusahaan yang baik, salah satunya dengan melakukan pengelolaan keuangan yang baik dan benar.

Adanya fenomena-fenomena yang terjadi membuat banyak pihak (para pemangku kepentingan) yang mulai berpikir bahwa penerapan tata kelola perusahaan yang baik (GCG) menjadi suatu kebutuhan. Lemahnya penerapan corporate governance diduga sebagai salah satu pemicu terjadi berbagai skandal keuangan bisnis perusahaan. Penerapan good corporate governance dinilai dapat memperbaiki citra perusahaan yang buruk, melindungi stakeholders serta meningkatkan kepatuhan terhadap peraturan perundang-undangan yang berlaku dan etika-eika umum pada dunia bisnis (Fitriyani, Tiswiyanti \& Prasetyo, 2015).

Pada tahun 2014, telah terbit Undang-Undang (UU) No.23 Tahun 2014 tentang Pemerintah Daerah. Dalam UU tersebut BUMD disebutkan sebagai badan usaha yang seluruh atau sebagian besar modalnya dimiliki oleh daerah. Bentuk dari BUMD menurut UU tersebut dapat berupa Perusahaan 
Umum Daerah (seluruh modalnya dimiliki oleh satu daerah) dan Perusahaan Perseroan Daerah (berbentuk PT dengan saham seluruhnya atau paling sedikit 51\% dimiliki oleh satu daerah). Dalam UU ini sudah mengatur secara umum mengenai penerapan GCG di BUMD. Pada pasal 343, disebutkan bahwa pengelolaan BUMD paling sedikit harus memenuhi 14 (empat belas) unsur. Terkait dengan GCG, maka unsur poin ke 4 (empat) yaitu "Tata kelola perusahaan yang baik" merupakan unsur yang harus ada dalam pengelolaan BUMD. Dengan kata lain dalam UU sudah mewajibkan, maka yang dibutuhkan selanjutnya dalam penerapan dan/atau pelaksanaannya adalah adanya peraturan turunan, baik Peraturan Pemerintah ataupun Peraturan Daerah.

Hal ini menunjukan pelaksanaan asas GCG memang tidak hanya penting dilaksanakan oleh perusahaan besar namun sangat perlu juga disadari dan diterapkan secara penuh dan konsisten oleh perusahaan dengan skala menengah maupun kecil. Seperti halnya BUMN, pada dasarnya BUMD (Perusahaan Daerah) pun harus menerapkan GCG dalam pengeloloaan usahanya. Praktik good corporate governance dapat menjamin dan melindungi para stakeholders dari kepentingan pribadi manajer. Corporate Governance menciptakan mekanisme dan alat kontrol untuk memungkinkan terciptanya sistem pembagian keuntungan dan kekayaan yang seimbang bagi stakeholder dan menciptakan efisiensi bagi perusahaan (Nuswandari, 2009).

Penelitian ini menganalisis bagaimana pengelolaan PD Pasar Kota Manado dalam mewujudkan GCG terkait dengan asas-asas GCG. Asas GCG dalam penelitian ini adalah asas GCG yang tercantum dalam Pedoman Umum Good Corporate Governance Indonesia yang dikeluarkan oleh Komisi Nasional Kebijakan Governance (KNKG), yaitu transparansi (transparency), akuntabilitas (accountability), responsibilitas (responsibility), independensi (independency), dan kewajaran dan kesetaraan (fairness).

Asas GCG oleh KNKG yang digunakan pada penelitian ini dipilih karena pada pendahuluan poin ke 6 dan 7 (enam dan tujuh) dalam Pedoman Umum GCG Indonesia yang dikeluarkan oleh KNKG sudah jelas mengatur bahwa pedoman GCG ini dikeluarkan bagi semua perusahaan di Indonesia termasuk perusahaan yang beroperasi atas dasar prinsip syariah. Perusahaan yang sahamnya tercatat di bursa efek, perusahaan negara (BUMN), perusahaan daerah (BUMD), perusahaan yang menghimpun dan mengelolah dana masyarakat, dan perusahaan yang produk atau jasanya digunakan oleh masyarakat luas, serta perusahaan yang mempunyai dampak luas terhadap kelestarian lingkungan, diharapkan menjadi pelopor dalam pelaksanaan GCG ini. Regulator juga diharapkan dapat menggunakan pedoman GCG ini sebagai acuan dalam menyusun pertauran terkait serta sanksi yang perlu dikenakan" (KNKG, 2006:2).

Berdasarkan latar belakang tersebut, analisis pengelolaan PD Pasar Kota Manado dalam mewujudkan GCG dilakukan di PD Pasar yang merupakan salah satu BUMD Milik Pemkot Manado. Pemilihan BUMD tersebut dikarenakan adanya fenomena-fenomena yang terjadi salah satunya berkaitan dengan kurang baiknya pengelolaan keuangan pada PD Pasar (tata kelola perusahaan yang baik).

Tujuan penelitian ini untuk: 1) menganalisis kesesuaian pengelolaan PD Pasar dengan asasasas GCG yaitu transparansi, akuntabilitas, responsibilitas, independensi, serta kewajaran dan kesetaraan dalam mewujudkan GCG; 2) menganalisis kendala-kendala yang dihadapi dalam pengelolaan PD Pasar Kota Manado dalam mewujudkan GCG baik dari asas transparansi, akuntabilitas, responsibilitas, independensi, serta kewajaran dan kesetaraan; 3) menganalisis upaya yang dilakukan Pemerintah Daerah Kota Manado maupun Direksi PD Pasar guna memperbaiki pengelolaan PD Pasar dalam mewujudkan GCG terkait asas transparansi, akuntabilitas, responsibilitas, independensi, serta kewajaran dan kesetaraan.

\section{Metode Penelitian}

Penelitian ini menggunakan metode penelitian kualitatif dengan pendekatan eksploratori (exploratory approach). Metode penelitian kualitatif dengan pendekatan eksploratori dipilih oleh peneliti untuk mendapatkan informasi yang lebih lengkap, mendalam sampai pada titik jenuh dimana informasi-informasi yang didapatkan memiliki kesamaan maksud dan/atau makna, kredibel dan bermakna dengan melakukan wawancara kepada individu yang terlibat dalam aktivitas dan proses pengelolaan perusahaan yang didasarkan pada adanya fenomena kurang optimalnya pengelolaan perusahaan sehingga perlunya tata kelola perusahaan yang baik (GCG).

Pengumpulan data dengan teknik wawancara mendalam dimulai dari beberapa informan kunci, pada awal penelitian sebanyak 9 (sembilan) orang yang memenuhi kriteria. Kesembilan informan kunci kemudian menjadi sumber informasi tentang orang lain yang juga dapat dijadikan 
informan kunci. Orang-orang yang ditunjukan ini kemudian dijadikan informan kunci dan selanjutnya diminta untuk menunjukan orang lain lagi yang memenuhi kriteria menjadi informan kunci. Demikian prosedur ini dilanjutkan sampai jumlah dan data penelitian terpenuhi dan/atau tercapai. Dalam proses pengumpulan data, peneliti juga menggunakan teknik snowball sampling. Guna pertimbangan keakuratan data hasil penelitian, peneliti mendapat 5 (lima) orang informan lagi yang dinilai sebagai informan kunci. Namun pada saat penelitian ada 3 (tiga) orang informan kunci yang dianggap peneliti kurang memenuhi kriteria yaitu kurang pahamnya konsep tata kelola perusahaan (konsep penelitian peneliti). Pada akhirnya, dalam penelitian ini hanya terdapat 11(sebelas) orang yang menjadi key informant yang akuntabel dalam memberikan informasi terkait masalah yang diteliti oleh peneliti. Informan tidak dilihat dari jumlahnya tetapi tergantung dari kelengkapan dan kedalaman data yang dapat dikumpulkan oleh peneliti.

Teknik pengumpulan data yang dilakukan dalam penelitian ini adalah wawancara, studi dokumentasi dan observasi atau gabungan ketiganya yang disebut triangulasi. Informan kunci ditetapkan secara purposive sampling dengan syarat memenuhi kriteria yang ditetapkan untuk mendapatkan informasi yang tepat dan akurat. Teknik analisis data yang digunakan dalam penelitian ini adalah teknik analisis Model Milles dan Huberman dalam Sugiyono (2015:85) yang terdiri atas data reduction, data display dan drawing conclusion/verification yang dilakukan secara interaktif dan berlangsung secara terus menerus sampai tuntas, sehingga datanya mencapai jenuh.

Data yang terkumpul kemudian diolah, dibuat transkrip data, kemudian dianalisis menggunakan analisis isi (content analysis), diberi kode, dan dikategorikan kedalam tema. Data tersebut disandingkan, dilakukan triangulasi antara sumber data dengan data lainnya sehingga didapat kesimpulan akhir, serta saran dari peneliti.

\section{Analisis dan Pembahasan}

Penelitian ini telah dilaksanakan di PD Pasar Kota Manado pada bulan Juli hingga September 2017. Dilakukan pendalaman tentang pengelolaan PD Pasar Kota Manado dalam mewujudkan GCG dengan cara melakukan wawancara mendalam (indepth interview) terhadap key informant selama 30 sampai 120 menit, dokumentasi terhadap dokumen-dokumen keuangan dan non-keuangan, serta observasi terhadap situasi dan kondisi tata kelola di PD Pasar termasuk sarana dan prasarana yang tersedia sesuai atau tidak dengan pernyataan dan/atau informasi yang didapat dari para key informant.

\section{Kesesuaian Pengelolaan PD Pasar Kota Manado dengan Asas-Asas Good Corporate Governance oleh KNKG}

Penelitian ini menganalisis bagaimana pengelolaan PD Pasar Kota Manado dalam mewujudkan GCG terkait dengan asas-asas GCG. Asas GCG dalam penelitian ini adalah asas GCG yang tercantum dalam Pedoman Umum GCG Indonesia yang dikeluarkan oleh KNKG, yaitu transparansi (transparency), akuntabilitas (accountability), responsibilitas (responsibility), independensi (independency), dan kewajaran dan kesetaraan (fairness) yang dijelaskan sebagai berikut.

1. Pengelolaan PD Pasar Manado dalam memenuhi asas transparansi, pedoman pokok pelaksanaan menurut KNKG sudah sesuai dan telah dilaksanakan, yaitu kebijakan PD Pasar seperti terkait gaji, sudah tertulis dan secara proporsional dikomunikasikan kepada pemangku kepentingan. Namun ada pedoman pokok pelaksanaan belum sesuai dan/atau belum dilaksanakan, yaitu PD Pasar belum memperhatikan isi informasi, harus memadai dan diperhatikan ketepatan waktu informasi yang akan disampaikan, serta ketersediaan informasi untuk para pemangku kepentingan yang lain dan informasi yang disampaikan kepada pemangku kepentingan disampaikan tidak secara menyeluruh, hanya terbatas/cenderung pada informasi kondisi keuangan.

2. Terkait asas akuntabilitas dalam pengelolaan PD Pasar, pengelolaan PD Pasar sudah sesuai dan telah dilaksanakan, yaitu PD Pasar telah menetapkan rincian tugas dan tanggung jawab untuk setiap personil dan sudah ada ukuran kinerja bagi personil PD Pasar, serta adanya sistem rewards and punishment. Namun ada pedoman pokok pelaksanaan belum dilaksanakan, seperti kurangnya karyawan yang memiliki kemampuan sesuai dengan tugas dan tanggungjawab, tidak adanya sistem pengendalian internal yang efektif serta tidak adanya pedoman perilaku bagi karyawan.

3. Terkait asas responsibilitas, pedoman pokok pelaksanaan telah dilaksanakan, yaitu PD Pasar sebagai perusahaan berpegang pada prinsip kehati-hatian. Namun, dalam hal melaksanakan tanggungjawab terhadap masyarakat dan lingkungan, PD Pasar sendiri belum memiliki atau 
mempunyai dana khusus untuk CSR dan sudah 4 (empat) tahun tidak berkontribusi terhadap PAD Pemerintah Kota Manado.

4. Dalam hal pemenuhan asas independensi, pengelolaan PD Pasar telah sesuai dengan pelaksanaan di PD Pasar, yaitu pada dasarnya peraturan daerah sudah mengatur tentang kemandirian pengelolaan PD Pasar, namun memang pada prakteknya baik dari internal maupun eksternal perusahaan masih ada saling mendominasi serta adanya benturan-benturan kepentingan (conflict interest) dan itu merupakan suatu kendala yang dihadapi oleh PD Pasar.

5. Pengelolaan PD Pasar Manado dalam memenuhi asas kewajaran dan kesetaraan, PD Pasar sudah sesuai dan telah dilaksanakan, yaitu PD Pasar sudah menyediakan kegiatan/forum diskusi kepada pemangku kepentingan seperti pedagang dalam memberikan masukan dan menyampaikan pendapat. Ada pedoman pokok pelaksanaan belum sesuai dalam pelaksanaannya, dalam hal ini tanpa disadari perlakuan dalam hal pemenuhan informasi kepada para pedagang masih sering dikesampingkan dan pada keadaan yang terjadi dilapangan perekrutan karyawan belum dilakukan secara profesional dan proporsional.

Kendala Dalam Pengelolaan PD Pasar Kota Manado Dalam Mewujudkan GCG Terkait Asas Transparansi, Akuntabilitas, Responsibilitas, Independensi, Kewajaran dan Kesetaraan

Pengelolaan PD Pasar Kota Manado dalam mewujudkan GCG masih ditemukan beberapa kendala dalam setiap asas. Berikut rekapan hasil urutan jumlah kendala yang disajikan dalam Tabel 1.

Tabel 1. Rekapan Hasil Kendala Yang Ditemukan

\begin{tabular}{|c|c|c|}
\hline No. & Tema dalam Kendala-Kendala Yang Ditemukan & Jumlah \\
\hline \multirow[t]{6}{*}{1} & AKUNTABILITAS & 119 \\
\hline & 1. Kendala Struktur Birokrasi & 47 \\
\hline & 2. Kendala Sumber Daya & 38 \\
\hline & 3. Kendala Sikap Pelaksana & 17 \\
\hline & 4. Kendala Lingkungan Ekonomi, Sosial dan Politik & 10 \\
\hline & 5. Kendala Komunikasi & 7 \\
\hline \multirow[t]{5}{*}{2} & RESPONSIBILITAS & 38 \\
\hline & 1. Kendala Sumber Daya & 19 \\
\hline & 2. Kendala Sikap Pelaksana & 14 \\
\hline & 3. Kendala Komunikasi & 4 \\
\hline & 4. Kendala Lingkungan Ekonomi, Sosial dan Politik & 1 \\
\hline \multirow[t]{5}{*}{3} & KEWAJARAN DAN KESETARAAN & 36 \\
\hline & 1. Kendala Sikap Pelaksana & 15 \\
\hline & 2. Kendala Sumber Daya & 10 \\
\hline & 3. Kendala Lingkungan Ekonomi, Sosial dan Politik & 8 \\
\hline & 4. Kendala Komunikasi & 3 \\
\hline \multirow[t]{6}{*}{4} & TRANSPARANSI & 34 \\
\hline & 1. Kendala Komunikasi & 12 \\
\hline & 2. Kendala Sumber Daya & 10 \\
\hline & 3. Kendala Lingkungan Ekonomi, Sosial dan Politik & 7 \\
\hline & 4. Kendala Sikap Pelaksana & 3 \\
\hline & 5. Kendala Struktur Birokrasi & 2 \\
\hline \multirow[t]{6}{*}{5} & INDEPENDENSI & 27 \\
\hline & 1. Kendala Lingkungan Ekonomi, Sosial dan Politik & 18 \\
\hline & 2. Kendala Sikap Pelaksana & 4 \\
\hline & 3. Kendala Sumber Daya & 3 \\
\hline & 4. Kendala Struktur Birokrasi & 2 \\
\hline & TOTAI & 254 \\
\hline
\end{tabular}

Sumber: Data Hasil Olahan, 2017

Berdasarkan Tabel 1 asas akuntabilitas merupakan asas yang paling banyak memiliki kendala, yang kedua asas responsibilitas, kemudian asas kewajaran dan kesetaraan, yang keempat asas transparansi, dan yang kelima adalah asas independensi. Peneliti kemudian akan membahas kendalakendala yang dihadapi dalam pengelolaan PD Pasar berdasarkan urutan prioritas kendala, sebagai berikut.

1. Asas Akuntabilitas

Pertama kendala struktur birokrasi dalam asas akuntabilitas, yaitu belum adanya SOP perusahaan secara jelas dan belum dibakukan menyebabkan para karyawan tidak melaksanakan kegiatan-kegiatannya sesuai standar yang dibutuhkan. Selanjutnya, penyebaran tanggungjawab kegiatan-kegiatan atau aktivitas-aktivitas karyawan diantara beberapa unit kerja dalam prakteknya banyak tidak berjalan maksimal, seperti bagian pengembangan usaha yang pekerjaan kurang bahkan tidak ada sesuai dengan tupoksinya, sedangkan pada bagian umum banyak pekerjaan yang menumpuk ke bagian tersebut. Kendala lainya juga yaitu tidak adanya sistem pengendalian internal (SPI) yang efektif dalam pengelolaan PD Pasar, dalam hal pengawasan dan pengendalian hanya dilakukan oleh 
Banwas selaku perpanjangan tangan Pemerintah Kota (Walikota) dan jajaran direksi bidang masingmasing.

Menurut Edward III dalam Agustino (2016:140-141) yang mempengaruhi keberhasilan implementasi kebijakan publik adalah struktur birokrasi. Walaupun sumber daya untuk melaksanakan suatu kebijakan tersedia, atau para pelaksana kebijakan mengetahui apa yang seharusnya dilakukan, dan mempunyai keinginan untuk melaksanakan suatu kebijakan, kemungkinan kebijakan tersebut tidak dapat dilaksanakan atau direalisasikan karena terdapatnya kelemahan dalam struktur birokrasi. Kebijakan yang begitu kompleks menuntut adanya kerjasama banyak orang, ketika stuktur birokrasi tidak kondusif pada kebijakan yang tersedia, maka hal ini akan menyebabkan sumber daya-sumber daya menjadi tidak efektif dan menghambat jalannya kebijakan. Birokrasi sebagai pelaksana sebuah kebijakan harus dapat mendukung kebijakan yang telah diputuskan secara politik dengan jalan melakukan koordinasi dengan baik. Adanya bagian pengembangan uasaha dalam struktur PD Pasar yang tidak berjalan sebagaimana mestinya, tidak adanya SPI yang efektif menyebabkan sumber dayasumber daya menjadi tidak efektif dan menghambat jalannya suatu kebijakan yang akan diterapkan.

Kedua kendala sumber daya, yaitu banyaknya kendala sumber daya manusia (SDM), baik dari sisi tingkat pendidikan karyawan, kemampuan dalam berinovasi, dan kendala sumber daya wewenang dimana beberapa karyawan menyalahgunakan wewenang serta adanya fasilitas penunjang yang kurang memadai. Yusuf (2015) mendefinisikan SDM sebagai individu yang merancang dan memproduksi keluaran dalam rangka pencapaian strategi dan tujuan yang telah ditetapkan oleh organisasi. Tanpa individu yang memiliki keahlian atau kompetensi, maka mustahil bagi organisasi untuk mencapai tujuan. Sumber daya manusia inilah yang membuat sumber daya lainnya dapat berjalan. Kurangnya tingkat pendidikan yang memadai serta skill yang kurang dari karyawan karena adanya rekrutmen yang tidak proporsional dan tidak secara profesional sehingga membuat banyaknya karyawan yang menumpuk namun banyak karyawan yang memiliki tingkat pendidikan yang yang belum memadai serta skill yang kurang, seperti kurangnya kreatifitas dan inovatif dari para karyawan dalam melaksanakan tugas dan tanggungjawab.

Ketiga kendala sikap pelaksana/disposisi terbagi atas 2 faktor, yaitu pengangkatan birokrat dan faktor insentif. Faktor Sikap Pelaksana menurut Edward III dalam Tahir (2014) merupakan faktor penting ketiga dalam pendekatan mengenai studi implementasi kebijakan publik. Jika implementasi kebijakan diharapkan berlangsung efektif, para pelaksana kebijakan tidak hanya harus mengetahui apa yang harus dilakukan dan memiliki kapabilitas untuk melaksanakannya tetapi mereka juga harus mempunyai keinginan untuk melaksanakan kebijakan tersebut. Faktor pelaksana dalam pengelolaan PD Pasar adalah jajaran direksi PD Pasar Kota Manado. Kebijakan akan efektif apabila pelaksana mengerti, memahami apa yang tertuang dalam kebijakan tersebut, untuk itu dalam pengangkatan para pelaksana harus adanya fit and proper test, rekrutmen secara proporsional dan profesional.

Keempat kendala lingkungan ekonomi, sosial dan politik dapat dikatakan bahwa adanya kendala lingkungan ekonomi, sosial dan politik terkait asas akuntabilitas cukup berpengaruh terhadap pemilihan karyawan, tidak semua karyawan mempunyai kemampuan yang sesuai dan memadai, sehingga hal tersebut dapat menurunkan kinerja perusahaan. Menurut Van Metter dan Van Horn dalam Agustino (2016:135-136) adalah sejauh mana lingkungan eksternal turut mendorong keberhasilan kebijakan publik yang telah ditetapkan. Lingkungan sosial, ekonomi, dan politik yang tidak kondusif dapat menjadi penyebab dari kegagalan kinerja implementasi kebijakan. Oleh karena itu, upaya untuk mengimplementasikan kebijakan harus pula memperhatikan kekondusifan kondisi lingkungan eksternal. Akuntabilitas merupakan prasyarat yang diperlukan untuk mencapai kinerja yang berkesinambungan.

Kelima kendala komunikasi dalam pengelolaan PD Pasar tersebut, terdapat 3 (tiga) faktor komunikasi yaitu transmisi, kejelasan dan konsistensi. Kendala komunikasi terjadi antar pemegang saham dan/atau banwas dengan direksi, antar jajaran direksi dan PD Pasar dengan para pedagang.

Menurut Edward III dalam Agustino (2016:137-138) terdapat tiga indikator yang dapat dipakai dalam mengukur keberhasilan variabel komunikasi yaitu: 1) Transmisi; penyaluran komunikasi yang baik akan dapat menghasilkan suatu implementasi yang baik pula. Seringkali yang terjadi dalam penyaluran komunikasi adalah adanya salah pengertian (miskomunikasi), hal ini disebabkan karena komunikasi telah melalui beberapa tingkatan birokrasi di tengah jalan; 2) Kejelasan; komunikasi yang diterima oleh para pelaksana kebijakan (street-level-bureuarats) haruslah jelas dan tidak membingungkan (tidak ambigu/mendua). Ketidakjelasan pesan kebijakan tidak selalu mengahalangi impelementasi, pada tataran tertentu, para pelaksana membutuhkan fleksibelitas dalam 
melaksanakan kebijakan. Tetapi pada tataran yang lain hal tersebut justru akan menyelewengkan tujuan yang hendak dicapai oleh kebijakan yang telah ditetapkan; 3) Konsistensi; perintah yang diberikan dalam melaksanakan suatu komunikasi haruslah konsisten dan jelas (untuk diterapkan atau dijalankan). Ini karena jika perintah yang diberikan sering berubah-ubah, maka dapat menimbulkan kebingungan bagi pelaksana di lapangan.

Demikian pula dengan pengelolaan PD Pasar, apabila dalam pengelolaannya diterapkan fungsi komunikasi yang baik antara pemegang saham dan/atau banwas dengan direksi, antar jajaran direksi dan PD Pasar dengan para pedagang.

\section{Asas Responsibilitas}

Pertama kendala sumber daya terkait asas responsibilitas, yaitu SDM dan informasi, sumber daya disini adalah personil PD Pasar baik direksi maupun staf yang mengelola kegiatan usaha yang harus sesuai dengan prinsip korporasi yang sehat serta peraturan perundang-undangan yang berlaku. Menurut Agoes (2013:103) prinsip pertanggungjawaban (responsibility) adalah prinsip dimana para pengelola wajib memberikan pertanggungjawaban atas semua tindakan dalam mengelola perusahaan kepada para pemangku kepentingan sebagai wujud kepercayaan yang diberikan kepadanya. Keunggulan suatu organisasi ditentukan oleh keunggulan sumber daya yang dimiliki dan bagaimana memanajemeni sumber daya tersebut. Ini berkaitan dengan bagaimana meningkatkan kapabilitas SDM-nya untuk mampu merespon secara cepat dan tepat perubahan yang terjadi dan bagaimana organisasi memanfaatkan secara efisien dan efektif finansial, fisik, teknologi dan informasi untuk kepentingan organisasi (Silalahi, 2015:236). Belum ada dana khusus untuk CSR, perencanaan dan pelaksanaan yang memadai untuk diperuntukan dalam melaksanakan tanggung jawab sosial, seperti kepedulian terhadap masyarakat dan kelestarian lingkungan tidak maksimal dilaksanakan oleh PD Pasar.

Kedua kendala sikap pelaksana, yaitu pengangkatan birokrat yang dalam hal ini belum maksimalnya pengelolaan, sikap responsif pimpinan (direksi) PD Pasar dalam mempertanggungjawabkan hasil (laba) perusahaan secara maksimal sesuai yang diharapkan para pemegang saham/mitra. Menurut Edward III dalam Agustino (2016:140) menyatakan bahwa melakukan pengaturan birokrasi (staffing the bureaucracy); dalam konteks ini Edward III mensyaratkan bahwa implementasi kebijakan harus dilihat juga dalam hal pengaturan birokrasi. Ini merujuk pada penunjukan dan pengangkatan staf dalam birokrasi yang sesuai dengan kemampuan, kapabilitas, dan kompetensinya. Selain itu, pengaturan birokrasi juga bermuara pada 'pembentukan' sistem pelayanan publik yang optimal, penilaian personil dalam bekerja, hingga metode by passing personil. Personil yang diangkat untuk mengelola usaha di PD Pasar merupakan orang yang kurang kapabel dalam mengelola dan menghasilkan laba dalam hal pertanggungjawaban perusahaan, sehingga PD Pasar sebagai BUMD dalam kurang berkontribusi untuk PAD Pemerintah Kota Manado.

Ketiga kendala komunikasi, yaitu terjadinya salah pengertian (miskomunikasi) antara beberapa mitra dengan pihak PD Pasar terhadap aturan/ regulasi yang ada dalam pemenuhan tanggungjawab dari PD Pasar terhadap PAD dan belum signifikannya antara aturan satu dengan yang lain, jadi kadang masih "bertabrakan" aturan yang satu dengan lain, jadi seperti tumpang tindih dalam hal pertanggungjawaban. Perusahaan harus menetapkan rincian tugas dan tanggung jawab masingmasing organ perusahaan dan semua karyawan secara jelas dan selaras dengan visi, misi, nilai-nilai perusahaan (corporate values), dan strategi perusahaan (KNKG, 2006:6). Menurut Edward III dalam Agustino (2016:137) implementasi yang efektif terjadi apabila para pembuat keputusan sudah mengetahui apa yang akan mereka kerjakan. Pengetahuan atas apa yang akan mereka kerjakan dapat berjalan apabila komunikasi berjalan dengan baik, sehingga setiap keputusan kebijakan dan peraturan impelementasi harus ditansmisikan (atau dikomunikasikan) kepada bagian personalia yang tepat. Selain itu, kebijakan yang dikomunikasikan pun harus tepat, akurat, dan konsisten. Komunikasi (atau pentransmisian informasi) diperlukan agar para pembuat keputusan dan para implementor akan semakin konsisten dalam melaksanakan setiap kebijakan yang akan diterapkan dalam masyarakat. Adanya komunikasi yang baik diperlukan oleh pimpinan (direksi) dalam menetapkan rincian tugas dan tanggungjawab secara jelas dan selaras kepada seluruh personil PD Pasar.

Keempat kendala lingkungan ekonomi, sosial dan politik, yaitu yaitu salah satunya organ perusahaan harus berpegang pada prinsip kehati-hatian, PD Pasar cenderung bersifat hati-hati berkaitan dengan data, karena pengalaman motivasi yang bagus dalam hal pertanggungjawaban kepada publik, tapi ternyata ada "pihak lain" yang memanfaatkan data tersebut untuk kepentingan pribadi dan/atau kelompok. 
Menurut Van Donal van Metter dan Carl van Horn dalam Agustino (2016:133) lingkungan sosial, ekonomi, dan politik yang tidak kondusif dapat menjadi penyebab dari kegagalan kinerja implementasi kebijakan. Perusahaan harus mematuhi peraturan perundang-undangan serta melaksanakan tanggung jawab terhadap masyarakat dan lingkungan sehingga dapat terpelihara kesinambungan usaha dalam jangka panjang dan mendapat pengakuan sebagai good corporate citizen. Organ perusahaan harus berpegang pada prinsip kehati-hatian dan memastikan kepatuhan terhadap peraturan perundang-undangan, anggaran dasar dan peraturan perusahaan (by-laws) (KNKG, 2006:6).

Seluruh organ PD Pasar harus berpegang pada prinsip kehati-hatian, adanya faktor eksternal seperti lingkungan ekonomi, sosial dan politik harus diperhatikan yaitu dalam hal pemenuhan asas resposnibilitas PD Pasar yang menyangkut data-data PD Pasar yang dapat dipolitisir oleh pihak-pihak tertentu.

3. Asas Kewajaran dan Kesetaraan

Pertama terkait asas kewajaran dan kesetaraan terdapat kendala sikap pelaksana, yaitu pengangkatan birokrat yaitu kurang baiknya manajemen PD Pasar, seperti dari sisi administrasi dan perekrutan karyawan serta penataan pedagang serta tidak adanya jenjang karir, seperti contoh start dari kabag, kabag ke direksi, tapi kalau di PD Pasar bisa staf jadi kabag, kabag turun jadi staf, direksi turun jadi staf jadi tidak tentu, jadi tidak paten kalau saat ini seseorang menjadi kabag, lalu akan naiknaik menjadi direksi atau akan tetap dikabag, dan gaji masih belum mengikuti UMP, serta tidak ada kenaikan gaji berkala.

Faktor Sikap Pelaksana menurut Edward III dalam Tahir (2014) merupakan faktor penting ketiga dalam pendekatan mengenai studi implementasi kebijakan publik. Jika implementasi kebijakan diharapkan berlangsung efektif, para pelaksana kebijakan tidak hanya harus mengetahui apa yang harus dilakukan dan memiliki kapabilitas untuk melaksanakannya tetapi mereka juga harus mempunyai keinginan untuk melaksanakan kebijakan tersebut. Faktor pelaksana dalam pengelolaan PD Pasar adalah jajaran direksi PD Pasar Kota Manado, terkait asas kewajaran dan kesetaraan pihak direksi wajib memperhatikan, menghargai dan memberikan perlakuan yang adil dan setara kepada karyawan maupun pedagang sesuai manfaat dan kontribusi yang diberikan kepada perusahaan, seperti pemberian insentif, jenjang karir, dan penataan pedagang.

Kedua, adanya kendala sumber daya yang terbagi atas 2 (dua) faktor SDM dan wewenang. Keberhasilan proses implementasi kebijakan sangat tergantung dari kemampuan memanfaatkan sumber daya yang tersedia. Manusia merupakan sumber daya yang terpenting dalam menentukan suatu keberhasilan proses implementasi. Tahap-tahap tertentu dari keseluruhan proses implementasi menuntut adanya SDM yang berkualitas sesuai dengan pekerjaan yang diisyaratkan oleh kebijakan yang telah ditetapkan secara politik. Tetapi ketika kompetensi dan kapabilitas dari sumber-sumber daya itu nihil, maka kinerja kebijakan publik sangat sulit untuk diharapkan.

Tetapi di luar SDM, sumber-sumber daya lain yang perlu diperhitungkan juga ialah sumber daya finansial dan waktu. Ini karena mau tidakmau ketika SDM yang kompeten dan kapabel telah tersedia sedangkan kucuran dana melalui anggaran tidak tersedia, maka akan timbul masalah untuk merealisasikan apa yang hendak dituju oleh tujuan kebijakan. Demikian pula halnya dengan sumber daya waktu. Saat SDM giat bekerja dan kucuran dana berjalan dengan baik, tetapi terbentur dengan masalah waktu yang terlalu ketat, maka hal ini pun dapat menjadi penyebab ketidakberhasilan suatu implementasi kebijakan.

Sumber daya yang ada di PD Pasar sangat diperlukan untuk dikelola dengan baik, setara dan wajar untuk seluruh para pemangku kepentingan, baik pemegang saham/mitra, karyawan, pedagang maupun masyarakat umum. Kendala sumber daya dalam PD Pasar baik SDM dan wewenang, tidak lepas juga adanya sumber daya finansial dan waktu yang memang dibutuhkan dalam proses pencapaian asas kewajaran dan kesetaraan terlebih dalam masalah pembangunan pasar.

Ketiga kendala lingkungan ekonomi, sosial dan politik, yaitu selain masalah perekrutan yang masih dipengaruhi faktor politik yang kurang profesional, ada juga soal salah satu reward bukan cuma dari insentif tapi dari juga promosi, misalnya kalau dia dianggap memiliki kemampuan intelektual, memiliki keahlihan wajar jika diberikan promosi jabatan, tetapi banyak kali di PD Pasar pertimbangannya bukan karena itu, kemampuan intelektual dan keahlihan kecakapan tapi ada faktor diluar itudalam hal asas kewajaran dan kesetaraan sangat perlu memperhatikan kepentingan seluruh pemangku kepentingan.

Menurut Agoes (2013:103) menyebutkan perlakuan yang setara antar pemangku kepentingan (fairness), yaitu perlakuan yang adil dan setara, baik pemangku kepentingan primer (pemasok, pelanggan, karyawan, pemodal) maupun pemangku kepentingan sekunder (pemerintah, masyarakat 
dan yang lainnya). Hal inilah yang memunculkan konsep stakeholders (seluruh pemangku kepentingan), bukan hanya kepentingan stockholders (pemegang saham) saja.

Keempat kendala komunikasi yang tidak terbangun rapi antara PD Pasar dengan pihak pedagang, yang menyebabkan miskomunikasi. Menurut Silalahi (2015:275) menyatakan komunikasi penting karena fungsinya dalam organisasi. Untuk komunikasi diperlukan karena dapat berfungsi salah satunya sebagai fungsi integratif. Melalui komunikasi dapat diintegrasikan pekerjaaan dan unit-unit sehingga antara karyawan dan manajer menunjukkan kepaduan (cohesiveness). Disamping itu komunikasi membantu memelihara hubungan sosial orgaisasional dann membangun kebersamaan orang-orang yang melakukan kerjasama. Untuk menghindari miskomunikasi antara pemangku kepentingan, setiap personil dari jajaran direksi sampai petugas lapangan haruslah menjalin komunikasi yang integral.

4. Asas Transparansi

Pertama terkait kendala komunikasi dalam asas transparansi, yaitu adanya masalah ketersediaan informasi karena belum terbangunnya komunikasi yang maksimal (miskomunikasi) antara jajaran direksi, direksi dengan banwas maupun dengan Komisi B selaku mitra serta para pedagang dan belum adanya sinkronisasi antar bagian yang ada di PD Pasar. Menurut Agoes (2013:103) Prinsip transparansi (transparancy), disebut juga prinsip keterbukaan artinya kewajiban bagi para pengelola untuk menjalankan prinsip keterbukaan dalam menyampaikan informasi juga mendorong arti bahwa informasi yang disampaikan harus lengkap, benar dan tepat waktu kepada semua pemangku kepentingan. Tidak boleh ada hal yang dirahasikan, disembunyikan, ditutup-tutupi atau ditunda-tunda pengungkapannya.

PD Pasar adalah suatu perusahaan yang dimiliki oleh Pemerintah Kota yang dikelola oleh pihak ketiga, dalam hal ini jajaran direksi. PD Pasar merupakan perusahaan yang dinamis, melibatkan banyak pemangku kepentingan didalamnya, yang menuntut adanya saluran komunikasi yang baik untuk mewujudkan tujuan perusahaan. Adanya kendala komunikasi-transmisi tidak dapat dipungkiri akan menghambat perusahaan dalam mewujudkan GCG.

Kedua kendala komunikasi, yaitu alur atau pelaporan informasi keuangan dan non-keuangan disampaikan tapi sifatnya tidak berkala, hanya situasi-situasi khusus, ada yang dibuat ada yang tidak. Instrumen untuk pelaporan masih dianggap kurang penting. Menurut KNKG (2006:5) Untuk menjaga obyektivitas dalam menjalankan bisnis, perusahaan harus menyediakan informasi yang material dan relevan dengan cara yang mudah diakses dan dipahami oleh pemangku kepentingan. Perusahaan harus mengambil inisiatif untuk mengungkapkan tidak hanya masalah yang disyaratkan oleh peraturan perundang-undangan, tetapi juga hal yang penting untuk pengambilan keputusan oleh pemegang saham, kreditur dan pemangku kepentingan lainnya.

PD Pasar sebagai BUMD Pemerintah Kota Manado yang mengelola sendiri seluruh kegiatan usahanya harus tetap melakukan koordinasi dan komunikasi dengan pemegang saham/mitra, dan dengan antar jajaran direksi. Direksi sebagai pengelola wajib melakukan langkah-langkah pro aktif dalam penyampaian informasi, begitu pula dengan para karyawan harus bersinergi antar bagian satu dengan bagian lainnya dalam satu perusahaan.

Ketiga kendala lingkungan ekonomi, sosial dan politik, yaitu sebagai perusahaan pemerintah suhu politik yang sangat kental ada di PD Pasar, dalam upaya transparansi, terbukanya pihak PD Pasar, ada orang-orang didalam maupun luar perusahaan yang terkadang mempolitisir setiap data, setiap apa yang sudah dikerjakan untuk kepentingan politik pribadi maupun kelompoknya. Walaupun adanya pengaruh lingkungan eksternal dalam hal transparansi, PD Pasar harus tetap berpegang pada asas keterbukaan dalam memenuhi informasi yang material dan relevan kepada para pemangku kepentingan dan kepada masyarakat publik secara umum. Menurut KNKG (2006:5) kebijakan perusahaan harus tertulis dan secara proporsional dikomunikasikan kepada pemangku kepentingan. PD Pasar yang berorientasi pada pelayanan publik mengharuskan masyarakat dan/atau LSM yang merupakan para pemangku kepentingan lainnya perlu diperhatikan oleh PD Pasar dalam hal pemenuhan informasi.

Keempat kendala sikap pelaksana, yaitu adanya pelaksanaan kebijakan oleh Direksi yang belum sesuai dengan keinginan dan/atau seizin/sepengetahuan Banwas. Variabel ketiga yang mempengaruhi keberhasilan implementasi kebijakan adalah disposisi. Hal-hal penting yang perlu dicermati pada variabel disposisi, menurut Edward III dalam Agustino (2016:139-140) adalah pengangkatan birokrat; disposisi atau sikap pelaksana akan menimbulkan hambatan-hambatan yang nyata terhadap implementasi kebijakan apabila personil yang ada tidak melaksanakan kebijakankebijakan yang diinginkan oleh pejabat-pejabat tinggi. Oleh karena itu, pemilihan dan pengangkatan 
personil pelaksana kebijakan haruslah orang-orang yang memiliki dedikasi pada kebijakan yang telah ditetapkan.

PD Pasar dalam hal transparansi, seharusnya direksi berpatokan pada Kepmendagri No.50 Tahun 1999 terkait tupoksi banwas yang kegiatan yang ada di PD Pasar itu harus sepengetahuan dan seizin/sepersetujuan Banwas, namun pada prakteknya ada beberapa hal pelaksanaan kebijakan dilapangan yang tidak seizin bahkan sepengetahuan banwas.

Kelima kendala struktur birokrasi, yaitu adanya aturan main atau standar (SOP) yang telah diatur oleh perdis yang ditolerir karena masalah perorangan dan membuat kurangnya transparansi secara merata serta belum adanya penyebaran tanggungjawab kegiatan-kegiatan atau aktivitasaktivitas karyawan diantara beberapa unit kerja, seperti kehumasan untuk memenuhi asas transparansi.

Menurut Edward III dalam Agustino (2016:140-141) yang mempengaruhi keberhasilan implementasi kebijakan publik adalah struktur birokrasi. Walaupun sumber daya untuk melaksanakan suatu kebijakan tersedia, atau para pelaksana kebijakan mengetahui apa yang seharusnya dilakukan, dan mempunyai keinginan untuk melaksanakan suatu kebijakan, kemungkinan kebijakan tersebut tidak dapat dilaksanakan atau direalisasikan karena terdapatnya kelemahan dalam struktur birokrasi. Kebijakan yang begitu kompleks menuntut adanya kerjasama banyak orang, ketika stuktur birokrasi tidak kondusif pada kebijakan yang tersedia, maka hal ini akan menyebabkan sumber daya-sumber daya menjadi tidak efektif dan menghambat jalannya kebijakan. Birokrasi sebagai pelaksana sebuah kebijakan harus dapat mendukung kebijakan yang telah diputuskan secara politik dengan jalan melakukan koordinasi dengan baik.

5. Asas Independensi

Yang pertama kendala lingkungan ekonomi, sosial dan politik dalam asas independensi, kendala yang ditemukan yaitu adanya intervensi-intervensi dari kelompok-kelompok tertentu dimasyarakat sosial seperti LSM, kelompok kepentingan yang mengatas namakan pembelaan kepada para pedagang, yang sebenarnya ada beberapa pedagang yang tidak ingin terganggu oleh "zona nyaman" yang mereka buat yang tidak sesuai dengan aturan PD Pasar yang berlaku serta adanya beberapa keputusan yang diambil masih dipengaruhi oleh kebijakan politik, seperti penerimaan dan penempatan karyawan yang belum maksimal dikarenakan tidak dilakukannya sesuai standar rekrutmen yang jelas, masih sangat dipengaruhi oleh intervensi politik, penerimaan karyawan bersifat "orderan".

Menurut KNKG (2006:6) Untuk melancarkan pelaksanaan asas GCG, perusahaan harus dikelola secara independen sehingga masing-masing organ perusahaan tidak saling mendominasi dan tidak dapat diintervensi oleh pihak lain. Adapun pedoman pokok pelaksanaannya sebagai berikut.

1. Masing-masing organ perusahaan harus menghindari terjadinya dominasi oleh pihak manapun, tidak terpengaruh oleh kepentingan tertentu, bebas dari benturan kepentingan (conflict of interest) dan dari segala pengaruh atau tekanan, sehingga pengambilan keputusan dapat dilakukan secara obyektif.

2. Masing-masing organ perusahaan harus melaksanakan fungsi dan tugasnya sesuai dengan anggaran dasar dan peraturan perundang-undangan, tidak saling mendominasi dan atau melempar tanggung jawab antara satu dengan yang lain.

Intervensi politik yang begitu kuat pada PD Pasar akan mempengaruhi kegiatan usaha dan pengelolaan PD Pasar dalam memenuhi asas independensi. Proses pemilihan tenaga kerja dan pengambilan keputusan sebenarnya sudah diatur oleh perda agar PD Pasar mandiri namun pada prakteknya intervensi politik masih mempengaruhi hal-hal tersebut.

Kedua kendala sikap pelaksana, yaitu institusi pengawas (Banwas) diberikan gaji oleh pihak PD Pasar, yang tidak bisa dipungkiri dapat terjadinya dominasi oleh pihak-pihak tertentu dan bisa berpengaruh pada unsur subjektifitas, serta adanya nilai intervensi yang begitu tinggi dari pemerintah dibagian pengangkatan/rekrutmen direksi.

Menurut Edward III dalam Agustino (2016:139-140) adalah pengangkatan birokrat; disposisi atau sikap pelaksana akan menimbulkan hambatan-hambatan yang nyata terhadap implementasi kebijakan apabila personil yang ada tidak melaksanakan kebijakan-kebijakan yang diinginkan oleh pejabat-pejabat tinggi. Faktor pelaksana dalam hal ini adalah banwas, banwas yang merupakan perpanjangan tangan dari pemegang saham, banwas harus bersikap independen dalam melaksanakan tupoksi dan dalam melaksanakan kebijakan daripada pemegang saham, bebas dari benturan kepentingan manapun, apalagi dari pihak jajaran direksi. 
Ketiga kendala sumber daya, yaitu belum adanya pemisahan fungsi antara bagian keuangan dan akuntansi, dan adanya pengaruh dalam pengambilan keputusan kepada pedagang dikarenakan adanya saling mendominasi antar pedagang dalam mencari pembeli. Menurut Hartono dan Nugrahanti (2014) mekanisme GCG berfungsi sebagai alat untuk mendisiplinkan pengelola agar mentaati kontrak yang telah disepakati, sehingga dengan adanya mekanisme tata kelola yang baik yang dilandasi prinsip-prinsip corporate governance ini diharapkan dapat mengurangi masalah keagenan dalam perusahaan yang kemudian dapat meningkatkan kinerja perusahaan. Oleh karena itu diperlukan corporate governance untuk mengurangi permasalahan keagenan antara pemilik dan manajer. Adanya pemisahaan pengelolaan perusahaan antara pemerintah dengan dewan direksi, dimana aset maupun penghasilan yang diperoleh oleh perusahaan dikelola sendiri oleh Dewan Direksi dapat menjadikan adanya potensi masalah keagenan pada PD Pasar Kota Manado.

Keempat kendala struktur birokrasi terkait independensi, yaitu adanya penyebaran aktivitasaktivitas ke beberapa unit kerja yang dapat dipengaruhi oleh kepentingan tertentu, seperti staf banwas berasal dari bagian umum dan termasuk dalam staf umum dan digaji oleh pihak PD Pasar. Dua karakteristik, menurut Edward III, yang dapat mendongkrak kinerja struktur birokrasi/organisasi kearah yang lebih baik, yaitu dengan melakukan salah satunya melaksanakan fragmentasi adalah upaya penyebaran tanggungjawab kegiatan-kegiatan atau aktivitas-aktivitas pegawai diantara beberapa unit kerja. Adanya pengaruh kepentingan lain atau benturan kepentingan dalam hal ini antara banwas dan jajaran direksi akan membuat penyebaran tanggungjawab kegiatan atau aktivitas direksi dan karyawan pada PD Pasar yang tidak maksimal.

Pada dasarnya, semua kendala dalam pengelolaan PD Pasar dalam mewujudkan Good Corporate Governance saling berhubungan satu dengan yang lainnya. Dimana kendala yang paling besar dihadapi untuk setiap asas GCG adalah kendala sumber daya dan lingkungan ekonomi, sosial dan politik.

\section{Upaya Yang Dilakukan Pemerintah Kota Manado Maupun Direksi Guna Memperbaiki Pengelolaan PD Pasar dalam Mewujudkan GCG (Terkait Asas Transparansi, Akuntabilitas, Responsibilitas, Independensi, serta Asas Kewajaran dan Kesetaraan}

Adapun upaya dalam mewujudkan GCG oleh pihak direksi maupun Pemerintah Kota sudah dilaksanakan, sudah ada kesadaran dalam mewujudkan asas-asas GCG tersebut dalam pengelolaan PD Pasar, sebagai berikut.

1. Upaya Dalam Asas Akuntabilitas

Pertama, PD Pasar berupaya untuk segera membuat SOP perusahaan yang baku, yang berkaitan dengan keuangan kemudian berkaitan dengan perizinan, pembayaran iuran pedagang, berkaitan dengan mekanisme, struktur badan perusahaan itu diperjelas. Artinya dari struktur itu akan tahu setiap orang dia bekerja apa, dia bertanggung jawab kepada siapa dan dimana posisinya. Kedua, rasionalisasi jumlah karyawan, pemanfaatan kembali direktorat pengembangan usaha sebagai sumber pendapatan lain untuk PD Pasar Kota Manado, serta pembentukan tim verifikasi dalam mengevaluasi dan menilai kinerja masing-masing karyawan. Yang ketiga, ada rekrutmen bersifat profesional, fit and proper test untuk jajaran direksi, sehingga "the right man in the right place" dan untuk personil PD Pasar diikut sertakan dalam kegiatan-kegiatan pelatihan sebagai bentuk pengahargaan kinerja yang baik. Keempat, pihak direksi mulai menanamkan pola-pola positif dalam bingkai profesional, membuat pola baku, sehingga siapapun yang masuk kemudian tidak terjebak lagi ke kesalahan-kesalahan yang lama yang sifatnya political. Menurut KNKG (2006:5) Perusahaan harus dapat mempertanggungjawabkan kinerjanya secara transparan dan wajar. Untuk itu perusahaan harus dikelola secara benar, terukur dan sesuai dengan kepentingan perusahaan dengan tetap memperhitungkan kepentingan pemegang saham dan pemangku kepentingan lain. Akuntabilitas merupakan prasyarat yang diperlukan untuk mencapai kinerja yang berkesinambungan.

2. Upaya Dalam Asas Responsibilitas

Yang pertama, PD Pasar berupaya untuk mengolah pendapatan dari PD Pasar dengan baik, untuk dapat membayar gaji secara full setiap bulan, tepat waktu dan memasukan di perdis soal pengaturan retribusi untuk bendi dan roda, soal parkirnya, agar terhindar dari penyelewengan wewenang dan sebagai tambahan pendapatan PD Pasar. Kemudian, adanya pembinaan, penataan kembali hal-hal yang tidak semestinya, kemudian baru sejak Agustus 2016 itu PD Pasar memberlakukan kontrak persewaan itu dikenakan pajak, pajak perseroan dan melakukan penyetoranr pajak. Ketiga, adanya pengkajian kembali tentang aturan yang relevan dengan keadaan sekarang, 
peraturan lama yang sudah tidak relevan diperbaharui, dibuat peraturan yang lebih relevan, serta jelas dan yang sah agar penerapannya dapat dipertanggungjawabkan. Perusahaan harus mematuhi peraturan perundang-undangan serta melaksanakan tanggung jawab terhadap masyarakat dan lingkungan sehingga dapat terpelihara kesinambungan usaha dalam jangka panjang dan mendapat pengakuan sebagai good corporate citizen (KNKG, 2006:6), begitu pula PD Pasar sebagai BUMD Pemerintah Kota Manado.

3. Upaya dalam Asas Kewajaran dan Kesetaraan

Pertama, saat ini Dirut mengevaluasi, menilai, dan kemudian memberikan insentif kepada karyawan yang memiliki prestasi kerja baik. Kemudian ada juga pengaturan penjenjangan karir seseorang serta kenaikan gaji berkala. Yang kedua, semua jajaran direksi, kabag harus bersama, bekerjasama dalam mengelola PD Pasar dan melaksanakan tugas secara profesional, sehingga tercipta rasa keadilan, setara. Komitmen dan konsisten dalam menjalankan tugas dan tanggungjawab, ada parameter yang dibuat baku dalam penilaian dan pengambilan sikap untuk mengindari like or disklike dan adanya penilaian ganda terhadap stakeholders (karyawan dan pedagang), pembagian lapak pedagang diundi secara resmi, di saksikan oleh saksi-saksi yang independen, serta tetap konsisten pada program yang sudah dicanangkan, contoh penataan pasar, perbaikan infrastruktur dan pembangunan pasar. Ketiga, dengan membuat kebijakan harus selalu diketahui oleh pedagang. Kemudian proses sosialisasi jalan, adanya pertemuan dan forum/diskusi rutin antar stakeholders. Menurut KNKG (2006:7) Dalam melaksanakan kegiatannya, perusahaan harus senantiasa memperhatikan kepentingan pemegang saham dan pemangku kepentingan lainnya berdasarkan asas kewajaran dan kesetaraan.

4. Upaya Dalam Asas Transparansi

Yang pertama, dengan kesungguhan membangun komunikasi yang baik. Kedua, setiap karyawan, kepala-kepala bagian wajib memasukan laporan perencanaan kerja dan laporan kerja, kerjaan yang dibuat sejak tanggal 1 sampai akhir bulan, laporan tersebut dilaporkan ke pimpinan direksi (direktur) masing-masing. Yang ketiga, PD Pasar sebagai BUMD dalam meujudkan GCG, mengupayakan untuk lebih transparansi yaitu salah satunya dengan meng-upload laporan keuangan secara transparan. Keempat, berupaya membuat aturan baku, sebagai standar, dasar, acuan dalam melaksanakan pekerjaan, serta ada bagian kehumasan yang pekerjaannya, ketika ada website, bidang kehumasan mengelola, data-data apa yang perlu diinput, apa-apa yang akan dikerjakan dan apa yang sudah dikerjakan PD Pasar tahun ini. Untuk menjaga obyektivitas dalam menjalankan bisnis, perusahaan harus menyediakan informasi yang material dan relevan dengan cara yang mudah diakses dan dipahami oleh pemangku kepentingan. Perusahaan harus mengambil inisiatif untuk mengungkapkan tidak hanya masalah yang disyaratkan oleh peraturan perundang-undangan, tetapi juga hal yang penting untuk pengambilan keputusan oleh pemegang saham, kreditur dan pemangku kepentingan lainnya (KNKG, 2006:5).

5. Upaya Dalam Asas Independensi

Pertama, yaitu semua elemen harus komitmen dan konsiten untuk bekerja bersama untuk membuat pasar menjadi lebih baik, untuk menghidari terjadinya dominasi oleh pihak manapun. Yang kedua, dengan berupaya komitmen terhadap kebijakan-kebijakan yang ada baik pimpinan sampai pada jajaran staf. Pimpinan dari pemegang saham sampai dengan direksi dan seluruh staf haruslah memiliki integritas, pemimpin harus konsisten pada komitmen yang telah dipilih. Menurut KNKG (2006:7) untuk melancarkan pelaksanaan asas GCG, perusahaan harus dikelola secara independen sehingga masing-masing organ perusahaan tidak saling mendominasi dan tidak dapat diintervensi oleh pihak lain.

\section{Penutup}

Kesimpulan dalam penelitian ini adalah: 1) dalam memenuhi asas transparansi pada pengelolaan PD Pasar, berdasarkan pedoman pokok pelaksanaan menurut KNKG sudah sesuai dan telah dilaksanakan, yaitu terkait dengan kebijakan PD Pasar seperti gaji, sudah tertulis dan secara proporsional dikomunikasikan kepada pemangku kepentingan. Kedua, asas akuntabilitas, pengelolaan PD Pasar sudah sesuai dan telah dilaksanakan, yaitu PD Pasar telah menetapkan rincian tugas dan tanggung jawab untuk setiap personil dan sudah ada ukuran kinerja bagi personil PD Pasar, serta adanya sistem rewards and punishment. Ketiga, asas responsibilitas, pengelolaan PD Pasar telah dilaksanakan, yaitu PD Pasar sebagai perusahaan berpegang pada prinsip kehati-hatian. Keempat, asas independensi, PD Pasar telah sesuai dengan pelaksanaan, yaitu pada dasarnya peraturan daerah sudah mengatur tentang kemandirian pengelolaan PD Pasar. Yang kelima, asas kewajaran dan kesetaraan, pengelolaan PD Pasar sudah sesuai dan telah dilaksanakan, yaitu PD Pasar sudah menyediakan forum 
diskusi kepada pemangku kepentingan seperti pedagang dalam memberikan masukan dan menyampaikan pendapat; 2) dalam asas akuntabilitas terbagi atas kendala struktur birokrasi, kendala sumber daya, kendala sikap pelaksana, kendala lingkungan ekonomi, sosial dan ekonomi, serta kendala komunikasi, Dalam asas responsibilitas terbagi atas kendala sumber daya, kendala sikap pelaksana, kendala komunikasi, serta kendala lingkungan ekonomi, sosial dan ekonomi. Kendala dalam asas kewajaran dan kesetaraan terdiri dari kendala sikap pelaksana, kendala sumber daya, kendala lingkungan ekonomi, sosial dan politik serta kendala komunikasi. Dalam asas transparansi terdiri dari kendala komunikasi, sumber daya, lingkungan ekonomi, sosial dan politik, serta sikap pelaksana dan struktur birokrasi. Terkait asas independensi, kendalanya yaitu kendala lingkungan ekonomi, sosial dan politik, sikap pelaksana, sumber daya serta struktur birokrasi; 3) upaya dalam mewujudkan GCG oleh pihak direksi maupun Pemerintah Kota sudah dilaksanakan, seperti adanya perampungan SOP, struktur orgsnisasi baru, pemilihan, perekrutan dan/atau pengangkatan direksi dan karyawan secara transparan dan melalui fit and proper test, pengelolaan sumber daya secara efisien untuk dapat menghasilkan laba dalam berkontribusi pada PAD Kota Manado, penyampaian dan pelaporan informasi keuangan dan non-keuangan secara transparan pada seluruh pemangku kepentingan, serta komitmen dan konsiten untuk bekerja bersama untuk membuat pasar menjadi lebih baik, untuk menghidari terjadinya dominasi oleh pihak manapun.

Saran yang dapat diberikan dari penelitian ini adalah: 1) Bagi Direksi PD Pasar: Pelaksanaan GCG perlu dilakukan secara sistematis dan berkesinambungan oleh pihak direksi. Dalam pengelolaan PD Pasar untuk memwujudkan GCG PD Pasar dapat berpedoman pada pedoman umum GCG Indoenesia yang dikeluarkan oleh KNKG; 2) Bagi Dunia Akademis: Untuk mendapatkan hasil penelitian yang lebih akurat dari penelitian selanjutnya, hal yang bisa dilakukan adalah menambah key informant, seperti seluruh jajaran direksi, kemudian menambah beberapa key informant pembanding, seperti pedagang dan pemerhati PD Pasar (Ormas/LSM); 3) Bagi Pemerintah: Dengan semakin pentingnya peran BUMD dalam prekonomian baik nasional dan daerah, sudah sewajarnya bagi pemerintah untuk mengeluarkan pedoman GCG bagi BUMD.

\section{Daftar Pustaka}

Agoes Sukrisno. 2013. Auditing: Petunjuk Praktis Pemeriksaan Akuntan oleh Akuntan Publik. Edisi 4. Buku 2. Jakarta: Salemba Empat.

Agustino Leo. 2016. Dasar-dasar Kebijakan Publik. Bandung: Alfabeta.

Fitrriyani Dewi, Tiswiyanti Wiwik, Prasetyo Eko. 2015. Praktik Good Corporate Governance dan Dampaknya Terhadap Kinerja Berdasarkan Balace Scorecard Pada Perusahaan Daerah Air Minum. Journal of World Class Islamic University.Universitas Jambi. Vol.2, No.1, Mei 2015: 91-103.

Hartono, D.F, Nugrahanti, Y.W. 2014. Pengaruh Mekanisme Corporate Governance terhadap Kinerja Keuangan Perusahaan Perbankan. Jurnal Dinamika Akuntansi, Keuangan, dan Perbankan. Vol.3, No.2: 191-205.

Komite Nasional Kebijakan Governance. 2006. Pedoman Umum Good Corporate Governance Indonesia. Jakarta: Komite Nasional Kebijakan Governance.

Nuswandari Cahyani. 2009. Pengaruh CGPI terhadap Kinerja Perusahaan pada Perusahaan yang Terdaftar di Bursa Efek Jakarta.Jurnal Bisnis dan Ekonomi. Universitas Stikubank. Semarang. Vol.16, No.2: 70-84.

Pemerintah Republik Indonesia. 2014. Undang-Undang Nomor 23 Tahun 2014 tentang Pemerintah Daerah.

Santo Da Maria Fransiska. 2016. Urgensi di Terapkannya Prinsip Good Corporate Governance pada Pengelolaan Perusahaan Daerah. Jurnal Hukum. Fakultas Hukum: Universitas Katolik Widya Mandira. Kupang. Jilid 45, No.3, Juli 2016: 181-190.

Silalahi Marto. 2015. Kebijakan Publik. Cetakan ke-1. Bandung:Yuma Pustaka.

Sugiyono. 2015. Metodologi Penelitian Kuantitatif, Kualitatif dan Kombinasi (mixed methods). Bandung: Alfabeta.

Tahir, Arifin. 2014. Kebijakan Publik dan Transparansi Penyelenggaraan Pemerintah. Bandung:Alfabeta

Turiman Fachturahman Nur. 2011. Terobosan Hukum Memajukan Badan Usaha Milik Daerah (BUMD) Dalam Era Otonomi Daerah. Artikel. Rajawali Garuda Pancasila.http://rajawaligarudapancasila.blogspot.co.id/2011/04/terobosan-hukummemajukan-badan-usaha.htmldiakses pada tanggal 4 Juni tahun 2017. 
Yusuf Zainal Abidin. 2015. Manajemen Komunikasi Filosofi, Konsep, dan Aplikasi. Bandung: CV Pustaka Setia. 